\title{
The Influence of Financial Knowledge, Financial Socialization, Financial Behaviour, and Financial Strain on Young Adults' Financial Well-Being
}

Mohamad Fazli Sabri, Mervin Anthony, Rusitha Wijekoon, Siti Shazwani Ahmad Suhaimi, Husniyah Abdul Rahim, Amira Shazana Magli \& Muhammad Pisol Mat Isa

To Link this Article: http://dx.doi.org/10.6007/IJARBSS/v11-i12/11799 DOI:10.6007/IJARBSS/v11-i12/11799

Received: 18 October 2021, Revised: 21 November 2021, Accepted: 04 December 2021

Published Online: 18 December 2021

In-Text Citation: (Sabri et al., 2021)

To Cite this Article: Sabri, M. F., Anthony, M., Wijekoon, R., Suhaimi, S. S. A., Rahim, H. A., Magli, A. S., \& Isa, M. P. M. (2021). The Influence of Financial Knowledge, Financial Socialization, Financial Behaviour, and Financial Strain on Young Adults' Financial Well-Being. International Journal of Academic Research in Business and Social Sciences, 11(12), 566-586.

Copyright: (C) 2021 The Author(s)

Published by Human Resource Management Academic Research Society (www.hrmars.com) This article is published under the Creative Commons Attribution (CC BY 4.0) license. Anyone may reproduce, distribute, translate and create derivative works of this article (for both commercial and non0-commercial purposes), subject to full attribution to the original publication and authors. The full terms of this license may be seen at: http://creativecommons.org/licences/by/4.0/legalcode

Vol. 11, No. 12, 2021, Pg. 566 - 586

Full Terms \& Conditions of access and use can be found at http://hrmars.com/index.php/pages/detail/publication-ethics 


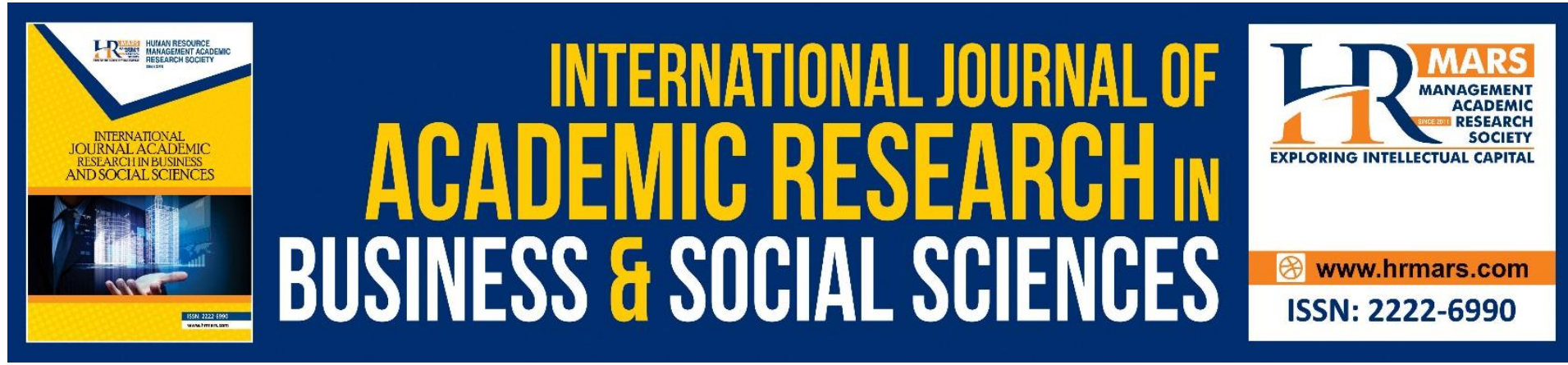

\title{
The Influence of Financial Knowledge, Financial Socialization, Financial Behaviour, and Financial Strain on Young Adults' Financial Well-Being
}

\author{
Mohamad Fazli Sabri ${ }^{1,2}$, Mervin Anthony ${ }^{1}$, Rusitha Wijekoon ${ }^{1}$, \\ Siti Shazwani Ahmad Suhaimi ${ }^{1}$, Husniyah Abdul Rahim ${ }^{1}$, Amira \\ Shazana Magli ${ }^{1} \&$ Muhammad Pisol Mat Isa ${ }^{3}$ \\ ${ }^{1}$ Faculty of Human Ecology, Universiti Putra Malaysia, 43400 UPM Serdang, Selangor. \\ ${ }^{2}$ Institute for Social Science Studies, Universiti Putra Malaysia, 43400 UPM Serdang, \\ Selangor, Malaysia, ${ }^{3}$ Department of Management \& Humanities, Universiti Teknologi \\ Petronas \\ Email: fazli@upm.edu.my
}

\begin{abstract}
Financial well-being refers to one's overall satisfaction with their current financial condition, and it plays a significant part in young adults' overall success as well as their ability to overcome psychological health concerns. It has become a crucial concern for individuals, households, societies, and countries in recent years, yet research on the subject is sparse and dispersed among fields. As a result, the current research assessed an empirical financial wellbeing model based on Malaysian young adults' financial knowledge, financial socialization, financial behavior and financial strain. A multi stage random sampling method was performed to draw a representative sample of Malaysian young adults, and 651 duly filled responses were received through the self-administered questionnaire. As stated by the multiple regression results, $16.1 \%$ of the total variance of financial well-being was clarified by the model. All four financial well-being determinants examined (financial knowledge, financial socialization, financial behavior, financial strain) were revealed significant, and only financial strain had a negative relationship with financial well-being. Therefore, current study has both the theoretical and practical contributions, and offers experts with actionable insights regarding the determinants of young adults' financial well-being when designing policies to uplift their financial well-being over time.
\end{abstract}

Keywords: Financial Knowledge, Financial Socialization, Financial Behaviour, Financial Strain, Financial Well-Being

\section{Introduction}

Young adults, who are between the ages of 18 and 29, are no longer reliant as children or adolescents, but have not yet acquired the responsibilities of normal adulthood (Arnett, 2001). They are often influenced by their actions and their surroundings. In terms of financial well-being, actions must be taken by them during young adulthood as financial mistakes in 
early adulthood at an early stage can prove to be costly in later life (Lusardi et al., 2010). During this stage, emerging adults require additional time and space to develop themselves in order to achieve self-sufficiency before they could care for others (Patterson, 2012). Furthermore, young adulthood is a period whereby proper dealing with the financial related factors of financial knowledge, financial behavior, financial socialization, and financial strain, and these influencers will help young adults to form behavioural intentions. Many researchers have found connections between an individuals financial well-being and their level of life satisfaction, for instance, (Ludban, 2015; Netemeyer et al., 2018; Shim et al., 2012). Hence, the importance of the four financial well-being determinants authors posit in this study, and focuses on young adults between the ages of 18-29 in line with definition adopted by Ranta (2020), as it best fits the Malaysian context. The country setting in Malaysia, is that individuals should be in a job by the age of 24 years old. As such, this would be the most appropriate benchmark for the categorization in this study.

One key issue of young adults is many are unaware of money management basics. The issue of young people's debt problem is evident by the formation of a centralized Credit Counselling agency by the Malaysian government. The Credit Counselling and Debt Management Agency (AKPK) stated that a total of 246,041 Malaysians from all walks of life have sought debt management help from AKPK since its establishment in 2006 (AKPK, 2018). In addition, 15\% of youth who enrolled in the AKPK's debt management programme worried about their poor financial management. Moreover, half of them were credit card debtors of under the age of 30 who had already declared as bankrupts. This is exacerbated if they do not have a good understanding of how to manage their money, which is almost usually the case with the vast majority of young adults (Mielitz et al., 2018). Furthermore, young adults tend to engage in high commitment assets hence derailing their financial well-being, a situation that was made worse by the COVID-19 pandemic as many young adults in Malaysia had reduced allowances or salary as well as some are experiencing job losses.

Thus, developing positive financial behaviour will entail habits of savings, following expenses, and being judicious with money, all of which will help young adults in attaining optimum financial well-being. All these attitudes must be incorporated early in their life so as to enable the attainment of financial well-being. Financial knowledge often remains the focal predictor of a youth's financial well-being (Riitsalu \& Murakas, 2019). In fact, many older individuals both in Malaysia and globally indicate that their financial well-being is impaired because they have not taken the right approaches during their young adulthood. As Hammond et al (2017), rightly pointed out that successful organization of financial matters is significant at each and every phase of the life-cycle, but comprehensive financial decision-making could grow more challenging as individuals grow older. Hence, the importance of young adults taking necessary steps to ensure their financial well-being from an earliest possible age.

In this regard, if young adults' have the right level of influences through financial knowledge, financial socialization, financial behaviour, and manageable financial strain, this could direct to a higher possibility of attaining financial well-being, a state in which a person can fulfil current and future demands, feel secure in the future, enjoy life, and manage with unforeseen needs in the future (Prendergast et al., 2018). As a result, the primary goal of this study is to look into the impacts of financial knowledge, financial socialisation, financial behaviour, and financial strain on the financial well-being of Malaysian young adults. 
The rest of the paper is organized as follows. Authors first presented literature review about the selected determinants and financial well-being. Afterward, methodology was explained that was used to conduct the survey, and then the results and discussion were presented. Finally, conclusion and implications for practice were given.

\section{Literature Review}

Financial Knowledge

Financial knowledge has become more significant than ever due to the increasing complexity in current financial market. As a result, consumers are taking on greater financial decisionmaking responsibilities, such as investing and saving (Garg \& Singh, 2018). Loke (2015) found many young working adults lack financial knowledge, and the findings which were in line with Balasubramnian and Sargent (2020), and they revealed that young adults who perceive their financial literacy to be "high" in spite of their low literacy tend to engage in high-risk financial behaviour. Thus, possessing an ample financial knowledge level is must for young adults.

A cross-national study was conducted by Organization for Economic Co-operation and Development (OECD, 2016) to measure the level of financial literacy in 28 countries, and the sample size used in the study consisted of 2,889 Malaysian adults. According to the findings, Malaysia was one of the countries that has to improve financial literacy among its citizens in order for people to completely grasp the decisions that they are making. The report also highlighted that the average literacy score of Malaysians was at 33\%.

According to Lusardi et al (2015), variation in financial knowledge was responsible for almost half of lifetime wealth inequality, and consequently suboptimal decision making in early adulthood as financial mistakes at an early stage could prove to be costly (Lusardi et al., 2010), particularly due to suboptimal use of the long-term compound interest effect. For young adults, the notion of increased complexity of financial products and increased choice is relevant as, after graduating from secondary school, students and young adults face increasingly complex and important financial decisions in the pursuit of financial well-being while balancing the temptations of a consumption-based global economy (Sundarasen, 2017).

Engels et al (2020) found that, those with more financial expertise are better at detecting fraud. Further, Joo and Grable (2004) revealed a mediating effect of financial knowledge on financial well-being. Individuals who have enhanced financial knowledge lead to having an improved saving behaviour (Henager \& Mauldin, 2015), preparing better retirement funds (Bucher-Koenen \& Lusardi, 2011), having less debt burden (French \& McKillop, 2016), and accumulating more wealth (Van Rooij et al., 2012). In addition, proper financial knowledge further improves the financial well-being (Gutter \& Copur, 2011; Henager \& Mauldin, 2015). Therefore, the formulated hypothesis is;

$\mathrm{H}_{1}$ : Financial knowledge is linked positively with financial well-being of young adults.

\section{Financial Socialization}

Based on the definition of Sundarasen et al (2016), financial socialization is "a proxy for individual interaction with socialization, for example, parents, friends, educators and the media are important among young adults toward optimization of money and wealth" (p. 145). Several studies, such as Lanz et al (2019); Rea et al (2019); Tang et al (2015), have verified the 
effectiveness of parental financial socialization among children and young adults. Barnea et al (2010) suggested that financial socialization happens when young adults look at their family members as well as role models to emulate. According to them, the family environment does have vital effect on financial behaviour of young individuals, but this influence is not long lasting because individuals gain personal experience as time passes. Still, however the fundamental knowledge of managing money and financial behaviour occurs when parents pass on their money beliefs about finances to their children with the fundamental aim that the socialization will have positive results on their children's long term financial well-being.

In confirming the influence of financial socialization on young adults, it was found that when less support was received from their parents during their childhood, a young adult takes a greater degree of awareness to self-search to make the right financial moves for their financial well-being. This finding was confirmed both in the Turkish context (Akben-Selcuk \& AltiokYilmaz, 2014), and in the Malaysian context (Sabri et al., 2010). Older students and students with lower income, respectively, who were less supported by their family have more advanced knowledge of financial concepts (Luksander et al., 2014) as by necessity these students must deal more intensively with personal finance matters.

Financial socialization has a direct impact on financial behaviour (Tang et al., 2015), and financial well-being (Rea et al., 2019). Furthermore, financial socialization was critical for young adults to establish positive financial behaviours (Drever et al., 2015). Financial socialization by parents had also been proven to influence young adults' financial behaviour, and financial well-being (Kim \& Chatterjee, 2013). This study considered parents as young adults' major financial socialization agents, and therefore, authors hypothesized that;

$\mathrm{H}_{2}$ : Financial socialization is linked positively with financial well-being of young adults.

\section{Financial Behaviour}

"Financial behaviour is a sum of financial decisions people make frequently in their everyday life, such as when they buy a cup of coffee, make a loan payment, transfer money to a savings account or sell stocks" (Xiao, 2008, p. 72). Further, financial behaviour is a strong predictor of financial well-being in the lives of young adults, and it demonstrates in the way they manage their personal financial resources by taking action. Credit card payments habits, loan financing choices, and the ability to budget income and expenditures are examples of financial behaviours (Mandigma, 2013). It has been repeatedly demonstrated that young individuals were not always capable of making sound financial decisions. Young adults who can make sound financial decisions will not face financial difficulties in the future and will demonstrate healthy financial behaviours. Accordingly, the way a young adult behaves will significantly affect his financial well-being (Ameliawati \& Setiyani, 2018; Gutter \& Copur, 2011).

Financial behaviour, according to Garman and Forgue (2006), could be a key factor in determining the financial well-being. Despite the fact that good financial habits improve financial well-being, failure to manage finances well is unfavorable and leads to financial difficulties. A growing body of evidence supports the hypothesis that if people engage in more positive financial behaviours, they will be more satisfied with their financial situations (Joo \& Grable, 2004). Furthermore, financial behaviours such as, budgeting, saving, compulsive 
buying, and credit management are strongly linked to financial well-being of youths (Gutter \& Copur, 2011). Hence, the hypothesis developed is;

$\mathrm{H}_{3}$ : Financial behaviour is linked positively with financial well-being of young adults.

\section{Financial Strain}

Financial strain is "a concept that is related to but distinctly different from poverty" (Ray et al., 2010, p. 8). Contrasting to poverty, financial strain shows how people perceive their financial state (Ray et al., 2010). Therefore, financial strain represents both the subjective as well as objective economic states (Gasiorowska, 2014). In the literature, financial strain is used interchangeably with financial stress. According to Hakkio and Keeton (2009, p. 15), several signs are accompanying with the financial stress, for example, "increased uncertainty about fundamental value of assets, decreased willingness to hold risky assets, increased uncertainty about behaviour of other investors, increased asymmetry of information, and decreased willingness to hold illiquid assets".

Taylor (2009) proposed that financial strain was one of the important predictors of financial well-being. It has also been recognized as a solid indicator of both psychological and physical well-being, which is particularly pertinent to low-income households who fight with the realisms of monetary requirements consistently (Kramer et al., 2019). Young people are a vulnerable population in terms of increased financial strain because emerging adulthood is a stage during which young adults develop a feeling of financial responsibility, and feel pressure from parents to achieve financial independence (Tanner et al., 2009). This translates to the impact of financial stress as a crucial factor of financial well-being among young adults, and hence, it links to the financial strain (Joo, 1998). Moreover, he stated that an individual's financial well-being is influenced by number of financially stressful events they have experienced. As a result, financial stress has been linked to financial well-being. In the Malaysian context, Delafrooz and Paim (2011) found financial stress as one of the most vital determinants of financial well- being. Thus, a hypothesis could be developed as;

$\mathrm{H}_{4}$ : Financial strain is linked negatively with financial well-being of young adults.

\section{Financial Well-Being}

Xiao (2008) described financial well-being as "a state of being financially healthy, happy, and free from worry and is based on subjective evaluation of one's financial situation" (p. 72). $\mathrm{O}^{\prime} \mathrm{Neill}$ et al. (2005) stated that financial well-being was the key element that influence individual well-being. Individuals who manage their finances well sustain positive well-being nevertheless, disruptions in their financial well-being have long-term consequences for their psychological, emotional, and relational well-being (Joo \& Grable, 2004).

In terms of the determinants of financial well-being discussed in this paper (financial knowledge, financial socialization, financial behavior, financial strain), Tanoto and Evelyn (2019) found that financial knowledge significantly influenced the financial well-being. As for financial socialization, Grohman et al (2015) classified parents as socialization agents who stimulate young adults saving attitudes, credit attitudes, gathering financial information and cultivating good financial behaviours which play a significant role for shaping their future financial well-being. As for financial behaviour, prior recent local studies (Mahdzan et al., 
2019; Sabri et al., 2020c) found that being financially healthy and happy are required to exhibit positive financial behaviours, such as regular savings, and proper credit management, and achieve higher financial well-being levels. Given the potential role of financial strain as a significant determinant of young adults' financial well-being, the AIF (Asian Institute of Finance, 2015) concluded that many millennials who are spending money impulsively, were experienced financial strain which hinders them in attaining financial well-being.

The influence of young adult's financial well-being has become of national importance in many jurisdictions including in Malaysia, with significant geared efforts undertaken to help young adults to attain financial well-being. Taken together, young adults who have good financial knowledge, are financially socialized, can exercise good financial behaviours, and have controlled financial strain are more likely to develop a financially prosperous life. Therefore, hypothesis could be constructed as;

$\mathrm{H}_{5}$ : Financial literacy, financial socialization, financial behaviour, and financial strain are significant determinants of financial well-being of young adults.

According to the above discussed literature, the theoretical framework constructed for the study is;

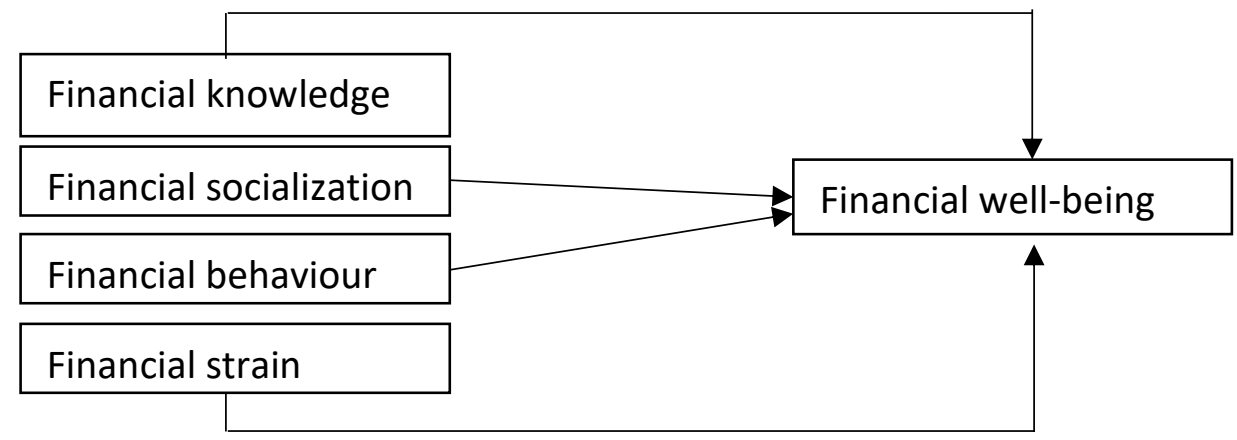

Figure1: Theoretical framework

\section{Research Methodology}

Sampling

In the current study, a total of 750 respondents from five (5) zones in Malaysia (i.e. Central, Southern, Northern, Eastern, and East Malaysia) were selected utilizing the multi-stage random sampling method, and therefore, 150 respondents were targeted from each zone. $A$ series of pre-tests were completed to guarantee the validity, and reliability of the questionnaire. Measurements have been validated for content and construct validities, apart from the reliability test. Content validity is assessed through reviews of items from past studies. As a result of final survey 651 duly completed questionnaires were received, and subjected to the data analysis. Descriptive analysis and multiple linear regression statistics were performed with SPSS version 26.

\section{Variables Measurement}

The financial knowledge of the respondents was assessed using Sabri et al (2010). It contains 11 questions with true and false answers. Respondent's financial socialization was assessed using Manfre (2017) with a measurement scale which was ranged from (1) strongly disagree to (5) strongly agree. Financial behavior was assessed using Kim (2004) which consists of ten 
items with a measurement scale from strongly disagree (1) to strongly agree (5). Young adults were asked to answer if they have come across eight circumstances that pointed out their financial strains where statements were from Delafrooz and Paim (2013). A mean score was used to conclude the financial stress of the responded young adults on a scale of " 1 " was the lowest score of financial stress (strongly disagree) and the scale " 5 " was the highest score of financial stress (strongly agree). The measurement of financial well-being in current research was grounded on the Financial Well-Being Scale established by the Consumer Financial Protection Bureau (2015) with consists of eight questions with a measurement scale ( $1=$ strongly disagree to $5=$ strongly agree). The reliability value for all of the variables is above 0.7 .

\section{Results and Discussion}

\section{Profile of the Respondents}

Out of 651 respondents number of female respondents was doubled (69.6\%) than that of male respondents $(30.4 \%)$. The participated respondents were categorized into five groups according to their age, and the lowest number of respondents were noted in the age category below 20 years (3.5\%), while highest number of young adults were recorded in the age group between 20 and 25 years (61.4\%). Most of the respondents were single (74.8\%), and the highest number of respondents were Malay (81.4\%), trailed by Chinese (9.5\%) and Indians (4.3\%). In terms of education level, $86.0 \%$ completed their tertiary education. Most of respondents $(53.5 \%)$ were students, and $29.8 \%$ were government and private sector employees. Only $10.4 \%$ was recorded under the category of unemployed. More than fifty percent $(57.6 \%)$ of the respondents did not have any income, because majority of the respondents in the sample were students and unemployed young adults. while $5 \%$ of them had more than 7,101 RM monthly income. When considering the monthly income of the spouse of married young adults, majority of them had $<\mathrm{RM} 2,500$, and $3.4 \%$ income was $>$ $\mathrm{RM} 7,101$.

\section{Financial Knowledge}

The findings of cash flow management showed that $96.6 \%$ of the young adults believed that they can control their expenses using shopping lists. It was also noted that $23.2 \%$ of the young adults answered "true" for the statement that said all Malaysian investments are legal, but $76.8 \%$ of the rspondents knew that the fact is not true. As cotributors of investment instruments, young adults must be aware of numerous tactics utilized by unscrupulous channels or platforms to attract them to invest their money in illegal investments. But, if young adults do not invest, they missd out lot of opprtunities, for example, higher financial confidence, risk tolerance ability, having greater financial peace of mind, and long-term financial habits. The concept of saving for crises must be ingrained in the $5.8 \%$ of respondents who answered "false" for the "true" statement that stated a $10 \%$ buffer fund for emergency situations is necessary.

Around half of the young adults (49.6\%) were illiterate in risk management as they think that all kinds of risk can be insured. In terms of Shariah-compliant financial products understanding, it is alarming to find that $49.6 \%$ of young adults thought that Shariahcompliant financial products were $100 \%$ risk-free. In the domain of estate planning, about less than one third of the respondents $(20.9 \%)$ were unaware that a person may distribute all of his property through a will. Referring to the knowledge on Malaysian financial institutions, 
only $57.6 \%$ of the young adults were aware of the role of AKPK. Last but not least, $90.8 \%$ understood the role of CCRIS, indicating that the Central Bank has been effective in clarifying the functions of CCRIS. Yet, more can still be done, as $9.2 \%$ of the youths were unaware of the role and functions of CCRIS (Table 1 ).

Table 1: Financial Knowledge

\begin{tabular}{|c|c|c|}
\hline & Statement & $\begin{array}{l}\text { Answered } \\
\text { Correctly }\end{array}$ \\
\hline 1. & Shopping lists help control spending. (True) & $(96.6 \%)$ \\
\hline 2. & All types of investments in Malaysia are legal. (False) & $(76.8 \%)$ \\
\hline 3. & Individuals need to save a minimum of $10 \%$ of their income. (True) & $(94.2 \%)$ \\
\hline 4. & All kinds of risk can be insured. (False) & $(50.4 \%)$ \\
\hline 5. & Shariah products are free from risk. (False) & $(51.0 \%)$ \\
\hline 6. & High risk investment has high invetsment returns. (True) & $(93.2 \%)$ \\
\hline 7. & A person may distribute all his property through a will. (True) & $(79.1 \%)$ \\
\hline $\begin{array}{l}8 . \\
\text { provide }\end{array}$ & $\begin{array}{l}\text { The Credit Counselling and Debt Management (AKPK) agency } \\
\text { es loan services. (False) }\end{array}$ & $(57.6 \%)$ \\
\hline $\begin{array}{l}9 . \\
\text { employ }\end{array}$ & $\begin{array}{l}\text { Private Retirement Scheme (PRS) are only for Goverment } \\
\text { yees. (False) }\end{array}$ & $(82.0 \%)$ \\
\hline $\begin{array}{l}10 . \\
\text { (True) }\end{array}$ & "High inflation means that the cost of living is increasing rapidly". & $(93.1 \%)$ \\
\hline $\begin{array}{l}11 . \\
\text { bureau }\end{array}$ & $\begin{array}{l}\text { "Central Credit Referencing Information System (CCRIS) is a credit } \\
\text { u that collect, process, store and create credit information". (True) }\end{array}$ & $(90.8 \%)$ \\
\hline
\end{tabular}

\section{Financial Socialization}

The mean scores of the financial socialization statements are given in the Table 2 . Based on the results, higher mean score shows respondent's positive financial socialization for the particular behaviour in personal finance, savings and financial attitude in managing financial management whereas lower mean score shows their less agreeableness.

Table 2 shows that most of the financial socialization elements were received by their parents, and highest contributory factor was "my parents have told me about the importance of saving", followed by "my parents have taught me how to be a smart consumer", and "my parents have a positive influence on me on managing money". Futher they mentioned that they have been taught by their parents on proper credit card usage, efficient family finance managing, and proper handling of financial matters. Past studies suggested that children learn financial socialization procedures from their families at their young ages, accordingly their future financial behaviours and financial well-being will be influenced (Gudmunson et al., 2015; Kim \& Chatterjee, 2013).

Sabri and MacDonald (2010) also stated that students' financial behaviour was governed by childhood financial knowledge, consumer experience, savings, and expenditure pattern. Previous research has recognized that numerous financial socialization outcomes of youths are implanted in the financial socialization procedures experienced in their childhood (Drever et al., 2015; Gudmunson et al., 2015; Shim et al., 2010). Jorgensen et al (2016) recently investigated the effect of financial socialization on financial decision making and found that those who have more opportunities to interact with and observe financial socialization agents 
make better financial judgments. Rea et al (2019) also verified the conclusions of the Financial Socialization Theory, which states that financially socialized people make better financial decisions when they become adults and achieve higher levels of financial well-being. Moreover, Sabri et al (2019) proved the gamification is one of the successful method via Smart Money Kit to enhance the financial literacy and money management skills among the Malaysian children to produce financially prudent consumers in the future.

Table 2: Respondents' Financial Socialization

Statement

Mean

1. "My parents have discussed family finances with me".

2. "My parents have told me about the importance of saving".

3. "My parents have taught me how to be a smart consumer".

4. "My parents have taught me how to use credit cards facilty accordingly".

5. "My parents and I have discussed how to obtain a good credit assessment".

6. "My parents have discussed how to fund university / college education fees with me".

7. "I make financial decisions based on what my parents have done in a similar situation".

8. "In financial management, I look at my parents as my role model".

9. "My parents became role models for me on how to manage financial matters".

10. "My parents have a positive influence on me on managing money". 4.17 Total mean score

The total mean score for the financial socialization of the sample was 39.54 , and the categorization of financial socialization is given in the Table 3.

Table 3: Categories of Financial Socialization

\begin{tabular}{ccc}
\hline Financial Socialization & $\mathbf{n}$ & \% \\
\hline Less socialize (score 10-30) & 94 & 14.5 \\
More socialize (score 31-50) & 555 & 85.5 \\
\hline
\end{tabular}

Based on the results of financial socialization of Malaysian young adults, majority of them (85.5\%) were more financially socialized.

\section{Financial Behaviour}

The mean scores of the financial behaviour statements are given in the Table 4. Based on the results, higher mean score shows respondent's positive financial behaviour for the particular behaviour in personal finance whereas lower mean score shows their less agreeableness.

Results showed that "I have long-term financial goals and strive to achieve them" was the item having higherst mean score trailed by "I check the price of the goods carefully before buying them", and "I save to meet personal / family financial goals". Financial goals are the key to working toward financial security and independence. Despite the strong belief that having more money and possessions will significantly improve people's lives, reliable evidence shows that individuals with strong financial goal orientations which are unreachable, less satisfied with their lives, less happy, and have more psychological problems 
(Garðarsdóttir et al., 2008; Kasser \& Kanner, 2004). However, better financial habits among financially distressed consumers are thought to play a substantial role in improving their health and financial well-being by reducing financial distress (O'Neill et al., 2005). Moreover, Sabri et al (2020a) stated that good financial practices, for example, "saving, budgeting, not carrying out any risky credit card behaviours, and less prone to compulsive buying, significantly expand the financial well-being" (p. 891). It was also discovered that Malaysian working women with good financial habits, as seen by their capacity to save and invest money properly, had greater levels of financial well-being (Sabri et al., 2020b).

Table 4: Respondents' Financial Behaviour

\begin{tabular}{|c|c|c|}
\hline & Statement & Mean \\
\hline 1. & "I spend according to my weekly or monthly budget". & 4.05 \\
\hline 2. & "I keep track of where my money is spent". & 3.46 \\
\hline 3. & "I set aside money for emergency expenses". & 3.94 \\
\hline 4. & I save to meet personal / family financial goals. & 4.18 \\
\hline 5. & I keep the purchase receipt. & 3.55 \\
\hline 6. & I make the minimum payment for a loan taken. & 3.31 \\
\hline 7. & I record my loan installment payment. & 3.49 \\
\hline 8. & I am late in paying my loan installment. & 2.31 \\
\hline 9. & I check the price of the goods carefully before buying them. & 4.33 \\
\hline 10. & "I have long-term financial goals and strive to achieve them". & 4.34 \\
\hline & Total mean score & 36.45 \\
\hline
\end{tabular}

Based on the respondents' total mean score for the financial behaviour, two groups could be identified, and the results are given in the Table 5.

Table 5: Categories of Financial Behaviour

\begin{tabular}{lcc}
\hline Financial Behaviour & $\mathbf{n}$ & \% \\
\hline Less practice (score 10-30) & 112 & 17.3 \\
Good practice (score 31-50) & 537 & 82.7 \\
\hline
\end{tabular}

Based on the financial behaviour results of Malaysian young adults, higher percentage (82.7\%) were followed good financial behavioural practices.

\section{Financial Strain}

Highest mean score was received for the statement "I worry if I am late paying the bill", and indicated that Malaysian consumers willing to pay the bills on time but if they were unable to do so, it did cause financial strain on them (Table 6). Moreover, worrying about paying bills, unsatisfaction on the current financial situation, unable to spend for basic necessities etc. were other financial starain related factors that were contributed actively to cause financial strain on individuals, and in their review on "causes and consequences of household financial strain" by French and Vigne (2019) found that the clear negative effect of those factors on consumers' mental health due to the anxiety and depression. Based on the previous studies households' low income was reported as one of the major factors that cause financial difficulties which affect for their psychological well-being (Ullah, 1990). 
Table 6: Respondents' Financial Strain

\begin{tabular}{|c|c|c|}
\hline & Statement & Mean \\
\hline 1. & I worry if I am late paying the bill. & 4.16 \\
\hline 2. & I could not sleep because I was worried about paying the bill. & 3.25 \\
\hline 3. & I get depressed and restless with my current financial situation. & 3.22 \\
\hline 4. & I can not afford (financially) to see a doctor when i am sick & 2.20 \\
\hline 5. & I cannot afford (financially) to get healthier food. & 2.31 \\
\hline 6. & I have high blood pressure due to financial difficulties. & 1.95 \\
\hline 7. & I am worried about medical expenses. & 2.60 \\
\hline 8. & I became depressed as a result of thinking about financial matters. & 2.66 \\
\hline \multicolumn{2}{|c|}{ Total mean score } & 22.35 \\
\hline
\end{tabular}

In terms of financial strain of the respondents', two categories; "less financial strain" and "more financial strain" could be identified, and the Table 7 shows the results.

Table 7: Categories of Financial Strain

\begin{tabular}{lcc}
\hline Financial Strain & $\mathbf{n}$ & $\mathbf{\%}$ \\
\hline Less strain (score 8-24) & 436 & 67.2 \\
More strain (score 25-40) & 213 & 32.8 \\
\hline
\end{tabular}

The respondents who were having the total mean score $25-40$ was considered as suffering with more financial strain, and low percentage $(32.8 \%)$ was reported.

\section{Financial Well-Being}

Based on the results (Table 8), higher mean score indicates better financial well-being of the respondents on the particular situation while lower mean score indicates less financial wellbeing. The findings showed that the respondents agreed that one would have a good financial well-being when they have enough money for daily expenses, afford to pay utility bills, afford to buy the item they want. However, it shows that the respondents were agreed of having less financial well-being when they were not having at least 3 months of income savings for emergency purposes, not able to achieve long-term financial goals and not having at least RM1,000 for emergency expenses.

It can be found that the respondents were agreed to have the highest financial well-being level when they have enough money for daily expenses whereby it shows the highest average score (Mean=3.90). The second highest score was about the ability to pay the utility bills. It can be expected that the young adults do not have difficulties with the item such "I have difficulties in paying monthly bills" and able to pay their utility bills before the due date, as it can help to avoid from late payment charges. Thus, it can help to improve their credit and lead to financial well-being. Meanwhile, the third highest score was about the ability to buy the items that they (Mean=3.71). It displays that the young adults have a good personal financial planning. A comprehensive financial plan would help to increase the quality of life and enhance the satisfaction by decreasing the ambiguity on financial needs. By having the ability to protect their finances, it also can help to avoid from financial worries. As per the Organization for Economic Co-operation and Development (OECD) in 2020, it is recommended that young adults should create personal financial plan in order to help them to boost the savings and protect their finances against financial loss. 
The statement related to I have at least three (3) months of income savings for emergency purposes reported the minimum average score of 3.10, and implied that respondents sometimes feel worried about their personal savings on the day they were asked the question. Zaimah study (2011) also recorded the lowest average score (Mean=5.20) among teachers aged 24 to 57 years old for the same statement. Due to the current economic condition and rising price of goods and services perhaps affect the feeling of the respondents on the day they were asked the question. There were two lowest mean scores that are 3.10 and 3.18 for the statements "I have at least three (3) months of income savings for emergency purposes" and "I am able to achieve long-term financial goals". Even though, the young adults financial well-being was in moderate level, they do not have steady income, because most of them were students and did not have a permanent job. Therefore, their financial vulnerability was higher, and hence, young adults might face difficulties in preparing income saving for at least three (3) months of income and might have a hard time in planning ahead for the long future goals. The current findings are in line with the study of (Abdullah et al., 2019).

Table 8: Financial Well-Being

Statement

1. I have enough money for daily expenses.

2. I can afford to buy the items I want.

3. I can afford to pay utility bills.

4. "I have a surplus of money at the end of the month".

5. I am able to achieve short-term financial goals (examples: buying furniture, electrical goods).

6. "I am able to achieve long-term financial goals (example: buying a house)".

7. I have at least RM1,000 for emergency expenses.

8. I have at least 3 months of income savings for emergency purposes.

According to the levels of the Malaysian young adults' financial well-being, majority of them (68.9\%) was found with the stage of more well-being, and the results are given in the Table 9.

Table 9: Categories of Financial Well-Being

\begin{tabular}{lcc}
\hline Financial Well-Being & $\mathbf{n}$ & $\mathbf{\%}$ \\
\hline Less well-being (score 8-24) & 202 & 31.1 \\
More well-being (score 25-40) & 447 & 68.9 \\
\hline
\end{tabular}

Hypotheses Testing

Pearson correlation analysis was conducted to investigate whether there were associations between financial literacy, financial socialization, financial behavior and financial strain with financial well-being. The results revealed significant and positive associations between financial literacy with financial well-being $(r=0.901, n=651, p=0.001)$, financial socialization with financial well-being $(r=0.282, n=651, p=0.001)$ and financial behaviour with financial well-being $(r=0.330, n=651, p=0.001)$. Meanwhile, the results also revealed that there was a significant and negative association between financial strain with financial well-being ( $r=-$ 0.133, $\mathrm{n}=651, p=0.001$ ) (Table 10). 
Fei et al (2020); Sabri et al (2020c) revealed that financial behaviour was a noteworthy negative association with the financial vulnerability of the young employees in Malaysia. Further, Sabri et al (2020c) also revealed a negative association between financial literacy and financial vulnerability. Moreover, financial vulnerability was negatively affected for financial satisfaction, and financial well-being of the female headed households in Malaysia (Sabri et al., 2021), and therefore both the financial behaviour and financial literacy have positive correlations with financial well-being. Furthermore, it was also confirmed by Sabri et al. in 2012.

Financial socialization agents, for instance, via parents and religion sources would enhance the financial well-being of the college students' (Sabri et al., 2012). Rea et al (2019) observed a positive correlation between young adults' financial well-being and family financial socialization. Results of Lanz et al (2019) indicated that family communication quality which is one of the major component of family financial socialization had an indirect, positive influence on subjective financial well-being via adoption of parents as a financial role model.

Sabri and Zakaria (2015) revealed a negative correlation between financial strain and young employees' financial well-being. Moreover, in their review Glenn et al (2021) on "community intervention strategies to reduce the impact of financial strain and promote financial wellbeing" highlighted the necessitates of community-led action to support societal recovery of financial strain to enhance the financial well-being and to minimize the negative impacts of COVID-19 pandemic on households financial well-being.

Table 10: Correlation Results for Financial Well-Being

\begin{tabular}{lc}
\hline \multicolumn{1}{c}{ Variables } & Pearson Correlation $(\boldsymbol{r})$ \\
\hline Financial knowledge & $0.091^{* *}$ \\
Financial socialization & $0.282^{* *}$ \\
Financial behaviour & $0.330^{* *}$ \\
Financial strain & $-0.133^{* *}$ \\
\hline
\end{tabular}

Significant: ${ }^{* *} p<0.001$

\section{Determinants of Young Adults' Financial Well-Being}

Table 11 shows that the F-value was 31.995, and significant with the p-value of 0.000 $(p<0.001)$. Therefore, the model was valid, and all four variables were revealed as significant predictors for financial well-being wth the $16.1 \%$ clarified variance of financial well-being. Financial behaviour $(\beta=0.276, p=0.000)$ was the major determinant of financial well-being, and followed by financial socialization $(\beta=0.170, p=0.000)$, financial strain $(\beta=-0.134, p=$ $0.001)$, and financial knowledge $(\beta=0.094, p=0.015)$. But, only financial strain reduces the financial well-being, and rest of the three variables have positive effects on individuals' financial well-being. Therefore, all five hypotheses tested were significant and accepted.

Different previous studies in various countries and contexts studied the determinants of financial well-being, and found several significant determinants, for example, financial strain, and financial behaviour (Mokhtar \& Husniyah, 2017); financial knowledge, financial strain, and financial behaviour (Mahdzan et al., 2019); financial knowledge, and financial behaviour (Sumani and Roziq, 2020); financial socialization (Ammerman \& Stueve, 2019; Pandey et al., 2020; Falahati et al., 2012). Hence, all four determinants were previously revealed as 
determinants of financial well-being in several studies for young adults as well as adult populations, and the results of the current research would be accepted.

Table 11: Multiple Regression Results for Financial Well-Being Determinants

\begin{tabular}{lcccc}
\hline \multicolumn{1}{c}{ Variable } & B & Beta & t & Sig. \\
\hline Financial Knowledge & 0.398 & 0.094 & 2.442 & $0.015^{*}$ \\
Financial Socialization & 0.149 & 0.170 & 4.177 & $0.000^{* *}$ \\
Financial Behaviour & 0.298 & 0.276 & 6.792 & $0.000^{* *}$ \\
Financial Strain & -0.137 & -0.134 & -3.471 & $0.001^{* *}$ \\
\hline
\end{tabular}

$\mathrm{R}=.407 ; \mathrm{R}^{2}=.166 ;$ Adjusted $\mathrm{R}^{2}=.161 ; \mathrm{F}=31.995 ;$ Sig. $\mathrm{F}=.000$

$* p<.05, * * p<.001$

\section{Conclusion, Implications and Future Research}

All five evaluated hypotheses as suggested in the study framework are empirically supported. Hence, the current study provides empirical evidence that the financial knowledge, financial behaviour, financial socialization, and financial strain have noteworthy impacts on the level of financial well-being of Malaysian young adults. Further, $16.1 \%$ of the variance of financial well-being was also clarified by the selected determinants. Among all the determinants directly linked with financial well-being in the proposed model, financial behaviour $(\beta=0.276$, $t=6.792, p=0.000)$ has the greatest influence trailed by financial socialization $(\beta=0.170, t=$ 4.177, $p=0.000)$, financial strain $(\beta=-0.134, t=-3.471, p=0.001)$, and financial knowledge $(\beta=0.094, t=2.442, p=0.015)$. All the predictors positively influenced the financial well-being except financial strain which was having a negative effect on the dependent variable.

The outcomes of the current study provide additional insight for Malaysian government, policymakers, and financial market players such as Bank Negara Malaysia and AKPK on the significance of implementing a holistic integration of educational programmes, particularly for the B40 group, who experience low financial well-being, financial behaviour, financial knowledge, financial literacy, and high financial strains. Without a doubt, this group, with lower income and education, is more vulnerable to a lack of financial education, making them easier to become culprits of financial stress and disasters. An effort should be taken to educate all stages of Malaysian households especially young adults by popularizing simple financial education methods, for example, Smart Money Kit (Sabri et al., 2019). Moreover, awareness programmes have to be implemented by giving special attention to some demographics of the audience, for instance, ethnicity and gender in order to get promising results (Sabri \& Wijekoon, 2019). Moreover, more comprehension on the identified determinants should be useful, especially finance related factors in rural poverty alleviation programmes (Wijekoon et al., 2021). Although, current research is restricted to Malaysia, its outputs and implications would be applicable to other emerging markets particularly those in Asia with comparable household distributions.

There are some limitations of the current study that should be acknowledged. First, this research looked at the financial well-being of a cross-sectional sample of households. A nationwide longitudinal research that can effectively capture the changes in the impact of the determinants on the participants over time will substantially increase a true investigation of the population. Second, $\mathrm{R}^{2}$ value which was resulted in multiple regression analysis was quite small; 0.161 which was not explained the large percentage of the variance of financial well- 
being (83.9\%). Such results could be due to four main independent variables which were used as determinants of financial well-being, namely, financial behaviour, financial socialization, financial strain, and financial knowledge. Future studies would utilize the other dimensions financial well-being, to investigate the significance of their effects on financial well-being. Additionally, future studies would also insert the other behavioural biases that might have indirect impacts on financial well-being. Final limitation of the research was that the data collected environment that people suffered with COVID-19 pandemic that might not reveal the real situation of the respondents.

\section{Acknowledgments}

This study was funded by the Geran Putra Universiti Putra Malaysia (UPM/800/2/2/4-Geran Putra - The Influence of Personal Finance and Psychological Factors on Financial Health among Malaysian Millennial Youth).

\section{References}

Abdullah, N., Fazli, S. M., \& Arif, A. M. M. (2019). The Relationship between attitude towards money, financial literacy and debt management with young worker's financial wellbeing. Pertanika Journal of Social Sciences and Humanities, 27(1), 361-387.

Akben-Selcuk, E., \& Altiok-Yilmaz, A. (2014). Financial literacy among Turkish college students: The role of formal education, learning approaches, and parental teaching. Psychological Reports, 115(2), 351-371.

AKPK. (2018). Financial behaviour and state of financial well-being of Malaysian working adults. Retrieved on 10/09/2021 from https://www.akpk.org.my/sites/default/files/ AKPK_ Financial\% 20Behaviour\%20and\%20 State\%20of\%20Finanical\%20Wellbeing\%20of\% 20Malaysian\%20 Working\%20Adult.pdf.

Ameliawati, M., \& Setiyani, R. (2018). The influence of financial attitude, financial socialization, and financial experience to financial management behavior with financial literacy as the mediation variable. In International Conference on Economics, Business and Economic Education 2018 (pp. 811-832). KnE Publishing.

Ammerman, D. A., \& Stueve, C. (2019). Childhood financial socialization and debt-related financial well-being indicators in adulthood. Journal of Financial Counseling and Planning, 30(2), 213-230.

Arnett, J. (2001). Conceptions of the transition to adulthood: Perspectives from adolescence through midlife. Journal of Adult Development, 8(2), 133-143.

Asian Institute of Finance. (2015). Finance matters: understanding gen y. Retrieved on 10/09/2021 from https://www.aif.org.my/clients/aif_d01/assets/multimediaMS/ publication/Finance_ Matters Understanding_Gen_Y_Bridging_the_Knowledge_Gap_of_Malaysias_Millennials.pdf.

Balasubramnian, B., \& Sargent, C. S. (2020). Impact of inflated perceptions of financial literacy on financial decision making. Journal of Economic Psychology, 80(2020), 102306, 1-16.

Barnea, A., Cronqvist, H., \& Siegel, S. (2010). Nature or nurture: what determines investor behavior? Journal of Financial Economics. 98, 583-604.

Bucher-Koenen, T. A. B. E. A, \& Lusardi, A. (2011). Financial literacy and retirement planning in Germany. Journal of Pension Economics \& Finance, 10(4), 565.

Consumer Financial Protection Bureau. (2015). Measuring financial well-being: A guide to using the CFPB financial well-being scale. Retrieved on 10/09/2021 from http://www. consumerfinance.gov/data-research/research-reports/financial-well-being-scale/. 
Delafrooz, N., \& Paim, L. H. (2011). Determinants of saving behavior and financial problem among employees in Malaysia. Australian Journal of Basic and Applied Sciences, 5(7), 222-228.

Delafrooz, N., \& Paim, L. H. (2013). Role of financial stress on the relationship between financial problems and financial wellness among Malaysian workers. African Journal of Business Management, 7(20), 1966-1972.

Drever, A. I., Odders-White, E., Kalish, C. W., Else-Quest, N. M., Hoagland, E. M., \& Nelms, E. N. (2015). Foundations of financial well-being: Insights into the role of executive function, financial socialization, and experience-based learning in childhood and youth. Journal of Consumer Affairs, 49(1), 13-38.

Engels, C., Kumar, K., \& Philip, D. (2020), Financial literacy and fraud detection. The European Journal of Finance, 26(4-5), 420-442.

Falahati, L., Sabri, M. F., \& Paim, L. H. J. (2012). Assessment a model of financial satisfaction predictors: Examining the mediate effect of financial behaviour and financial strain. World Applied Sciences Journal, 20(2), 190-197.

Fei, C. K., Sabri, M. F., Mohamed, N. A., Wijekoon, R., \& Majid A. Z. A. (2020). Determinants of financial vulnerability among young employees in Malaysia. Journal of Critical Reviews, 7(15), 3097-3107.

French, D., \& McKillop, D., (2016). Financial literacy and over-indebtedness in low-income households. International Review of Financial Analysis, 48, 1-11.

French, D., \& Vigne, S. (2019). The causes and consequences of household financial strain: A systematic review. International Review of Financial Analysis, 62, 150-156.

Garđarsdóttir, R. B., Janković, J., \& Dittmar, H. (2008). Is this as good as it gets? Materialistic values and well-being, in $\mathrm{H}$. Dittmar, Consumer society, identity, and well-being: The search for the 'good life' and the 'body perfect' (pp. 71-94). European Monographs in Social Psychology Series (Ed., Rupert Brown). London \& New York: Psychology Press.

Garg, N., \& Singh, S. (2018). Financial literacy among youth. International Journal of Social Economics, 45(1), 173-186.

Garman, E. T., \& Forgue, R. E. (2006). Personal Finance. Retrieved on 10/09/2021 from http:// www.financesitesearch.com/46074/personal-finance-by-garman-and-forgue- $8^{\text {th }}$ edition-2.

Gasiorowska, A. (2014). The relationship between objective and subjective wealth is moderated by financial control and mediated by money anxiety. Journal of Economic Psychology, 43, 64-74.

Glenn, N. M., Allen Scott, L., Hokanson, T., Gustafson, K., Stoops, M. A., Day, B., \& Nykiforuk, C. I. (2021). Community intervention strategies to reduce the impact of financial strain and promote financial well-being: A comprehensive rapid review. Global Health Promotion, 28(1), 42-50.

Grohman, A., Kouwenburg, R., \& Menkhoff, L. (2015). Childhood roots of financial literacy. Journal of Economic Psychology, 52, 114-133.

Gudmunson, C. G., Zuiker, V. S., Katras, M. J., \& Sabri, M. F. (2015). Enhancing personal and family finance courses using case studies. College Student Journal, 49(3), 321-330.

Gutter, M., \& Copur, Z. (2011). Financial behaviors and financial well-being of college students: Evidence from a national survey. Journal of Family and Economic Issues, 32(4), 699-714.

Hakkio, C. S., \& Keeton, W. R. (2009). Financial stress: What is it, how can it be measured, and why does it matter. Economic Review, 94(2), 5-50. 
Hammond, P. B., Mitchell, O. S., \& Utkus, S. P. (Eds.). (2017). Financial decision-making and retirement security in an aging world. Oxford University Press.

Henager, R., \& Mauldin, T. (2015). Financial literacy, the relationship to saving behavior in low-to moderate-income households. Family and Consumer Sciences Research Journal, 44(1), 73-87.

Joo, S. H. (1998). Personal financial wellness and worker job productivity. Unpublished doctoral dissertation, Virginia Tech, Blacksburg.

Joo, S. H., \& Grable, J. E. (2004). An exploratory framework of the determinants of financial satisfaction. Journal of Family and Economic Issues, 25(1), 162-171.

Jorgensen, B. L., Rappleyea, D. L., Schweichler, J. T., Fang, X., and Moran, M. E. (2016). The financial behaviour of emerging adults: A family financial socialization approach. Journal of Family Economic Issues, 38, 57-69.

Kasser, T., \& Kanner, A. D. (Eds.). (2004). Psychology and consumer culture: The struggle for a good life in a materialistic world. Washington, DC: American Psychological Association.

Kim, J. (2004). Impact of a workplace financial education program on financial attitude, financial behaviour, financial well-being, and financial knowledge. In: Proceedings of the Association for Financial Counseling and Planning Education (Vol. 22, No. 1, pp. 82-89).

Kim, J., \& Chatterjee, S. (2013). Childhood financial socialization and young adults' financial management. Journal of Financial Counseling and Planning, 24, 61-79.

Kramer, K. Z., Andrade, F. C. D., Greenlee, A. J., Mendenhall, R., Bellisle, D., \& Blanks, R. L. (2019). Periodic Earned Income Tax Credit (EITC) payment, financial stress and wellbeing: a longitudinal study. Journal of Family and Economic Issues, 40(3), 511-523.

Lanz, M., Sorgente, A., \& Danes, S. M. (2019). Implicit family financial socialization and emerging adults' financial well-being: A multi-informant approach. Emerging Adulthood, 8(6), 443-452.

Loke, Y. J. (2015). Financial knowledge and behaviour of working adults in Malaysia. MarginThe Journal of Applied Economic Research, 9(1), 18-38.

Ludban, M. (2015). Psychological well-being of college students. Undergraduate Research Journal for the Human Sciences, 14(1).

Luksander, A., Béres, D., Huzdik, K., \& Németh, E. (2014). Analysis of the factors that influence the financial literacy of young people studying in higher education. Public Finance Quarterly, 2, 221-241.

Lusardi, A., Michaud, P.-C., \& Mitchell, O. S. (2015). Optimal financial knowledge and wealth inequality. Journal of Political Economy, 1-48.

Lusardi, A., Mitchell, O. S., \& Curto, V. (2010). Financial literacy among the young. Journal of Consumer Affairs, 44(2), 358-380.

Mahdzan, N. S., Zainudin, R., Sukor, M. E. A., Zainir, F., \& Ahmad, W. M. W. (2019). Determinants of subjective financial well-being across three different household income groups in Malaysia. Social Indicators Research, 146(3), 699-726.

Mandigma, M. B. S. (2013). Relationship of financial capability (FC) with knowledge, skills and attitude: Evidence from Philippine Comprehensive University. World Journal of Social Sciences, 3(3), 28-45.

Manfre, M. (2017). Saving behavior: Financial socialization and self-control. Retrieved on 27/09/2021 from https://siecon3-607788.c.cdn77.org/sites/siecon.org/files/media_ wysiwyg/288-manfre.pdf 
Mielitz, K. K., MacDonald, M., \& Lurtz, M. (2018). Financial literacy education in a work release program for an incarcerated sample. Journal of Financial Counseling and Planning, 29(2), 316-327.

Mokhtar, N., \& Husniyah, A. R. (2017). Determinants of financial well-being among public employees in Putrajaya, Malaysia. Pertanika Journal of Social Sciences and Humanities, 25(3), 1241-1260.

Netemeyer, R. G., Warmath, D., Fernandes, D., \& Lynch Jr, J. G. (2018). How am I doing? Perceived financial well-being, its potential antecedents, and its relation to overall well-being. Journal of Consumer Research, 45(1), 68-89.

O’Neill, B., Xiao, J. J., Sorhaindo, B., \& Garman, E. T. (2005). Financial distressed consumers: Their financial practices, financial well-being, and health. Financial Counseling and Planning, 16(1), 73-87.

OECD. (2016), OECD/INFE international survey of adults' financial literacy competencies www.oecd.org/finance/oecd-infe-survey-adult-financial-literacycompetencies.htmOECD (2016b), Financial Education in Europe, OECD Publishing Paris.

Pandey, A., Ashta, A., Spiegelman, E., \& Sutan, A. (2020). Catch them young: Impact of financial socialization, financial literacy and attitude towards money on financial wellbeing of young adults. International Journal of Consumer Studies, 44(6), 531-541.

Patterson, P., Millar, B., Desille, N., \& McDonald, F. (2012). The unmet needs of emerging adults with a cancer diagnosis: a qualitative study. Cancer Nurs. 35(3): E32-40.

Prendergast, S., Blackmore, D., Kempson, E., Russell, R., \& Kutin, J. (2018). Financial wellbeing, A survey of adults in Australia. In, ANZ Melbourne, Australia.

Ranta, M., Silinskas, G., \& Wilska, T. A. (2020). Young adults' personal concerns during the COVID-19 pandemic in Finland: an issue for social concern. International Journal of Sociology and Social Policy, 40(9-10), 1201-1219.

Ray, K., Hoggart, L., Vegeris, S., \& Taylor, R. (2010). Better off working? Work, poverty and benefit cycling. Joseph Rowntree Foundation, York. Retrieved on 10/09/2021 from http://oro.open.ac.uk/38802/1/_userdata__ documents4_ctb44__Desktop_ Hoggart_work-poverty-benefits-full.pdf.

Rea, J. K., Danes, S. M., Serido, J., Borden, L. M., \& Shim, S. (2019). Being able to support yourself: Young adults' meaning of financial well-being through family financial socialization. Journal of Family and Economic Issues, 40(2), 250-268.

Riitsalu, L., \& Murakas, R. (2019). Subjective financial knowledge, prudent behaviour and income: The predictors of financial well-being in Estonia. International Journal of Bank Marketing, 37(4), 934-950.

Sabri, M. F., \& Wijekoon, R. (2019). The influence of gender and ethnicity on young adults' participation in financial education programme. Journal of Management and Sustainability, 9(1), 159-170.

Sabri, M. F., \& Zakaria, N. F. (2015). The Influence of financial literacy, money attitude, financial strain and financial capability on young employees' financial wellbeing. Pertanika Journal of Social Sciences \& Humanities, 23(4), 827-848.

Sabri, M. F., Cook, C. C., \& Gudmunson, C. G. (2012), Financial well-being of Malaysian college students. Asian Education and Development Studies, 1(2), 153-170.

Sabri, M. F., Dass, T. M., Burhan, N. A. S., Rahim, H. A., Wijekoon, R., \& Simanjuntak, M. (2021). Determinants of life satisfaction among female-headed households in Malaysia. International Journal of Business and Society, 22(1), 276-295. 
Sabri, M. F., MacDonald, M., Hira, T. K., \& Masud, J. (2010). Childhood consumer experience and the financial literacy of college students in Malaysia. Family \& Consumer Sciences Research Journal, 38(4), 455- 467.

Sabri, M. F., Rahim, H. A., Wijekoon, R., Zakaria, N. F., Magli, A. S., \& Reza, T. S. (2020c). The mediating effect of money attitude on association between financial literacy, financial behaviour, and financial vulnerability. International Journal of Academic Research in Business and Social Sciences, 10(15), 340-358.

Sabri, M. F., Reza, T. S., \& Wijekoon, R. (2020b). Financial management, savings and investment behaviour and financial well-being of working women in the public sector. Majalah Ilmiah Bijak, 17(2), 135-153.

Sabri, M. F., Wijekoon, R., \& Rahim, H. A. (2020a). The influence of money attitude, financial practices, self-efficacy and emotion coping on employees' financial wellbeing. Management Science Letters, 10(2020), 889-900.

Sabri, M. F., Wijekoon, R., Ramli, N. N., \& Dass, T. M. (2019). The impact of smart money kit on children's financial knowledge, attitude and behaviour. Journal of Social Sciences and Humanities, 3, 48-59.

Shim, S., Barber, B. L., Card, N. A., Xiao, J. J., \& Serido, J. (2010). Financial socialization of firstyear college students: The roles of parents, work, and education. Journal of Youth and Adolescence, 39(12), 1457-1470.

Shim, S., Serido, J., \& Tang, C. (2012). The ant and the grasshopper revisited: The present psychological benefits of saving for tomorrow. Journal of Economic Psychology, 33(1), 155-165.

Sumani, S., \& Roziq, A. (2020). Financial literation: Determinants of financial well-being in the batik small and medium industries in East Java. Jurnal Aplikasi Manajemen, 18(2), 289299.

Sundarasen, S. D. D., \& Rahman, M. S. (2017). Attitude towards money: Mediation to money management. Academy of Accounting \& Financial Studies Journal, 21(1), 1-17.

Sundarasen, S. D. D., Rahman, M. S., Othman, N. S., \& Danaraj, J. (2016). Impact of financial literacy, financial socialization agents, and parental norms on money management. Journal of Business Studies Quarterly, 8(1), 137.

Tang, N., Baker, A., \& Peter, P. C. (2015). Investigating the disconnect between financial knowledge and behavior: The role of parental influence and psychological characteristics in responsible financial behaviors among young adults. Journal of Consumer Affairs, 49 (2), 376-406.

Tanner, J. L., Arnett, J. J., \& Leis, J. A. (2009). Emerging adulthood: Learning and development during the first stage of adulthood. In M. C. Smith, \& N. DeFrates- Densch (Eds.), Handbook of research on adult development and learning (pp. 34-67). New York: Routledge.

Tanoto, S., \& Evelyn, E. (2019). Financial knowledge, financial wellbeing, and online shopping addiction among young Indonesians. Jurnal Manajemen dan Kewirausahaan, 21(1), 32-40.

Taylor, J. B. (2009). Getting Off Track: How Government Actions and Interventions Caused, Prolonged, and Worsened the Financial Crisis. Stanford, CA: Hoover Institution Press.

Ullah, P. (1990). The association between income, financial strain and psychological wellbeing among unemployed youths. Journal of Occupational Psychology, 63(4), 317330. 
Van Rooij, M. C. J., Lusardi, M., \& Alessie, R. (2012). Financial literacy, retirement planning and household wealth. The Economic Journal, 122(560), 449-478

Wijekoon, R., Sabri, M. F., \& Paim, L. (2021). Poverty: A literature review of the concept, measurements, causes and the way forward. International Journal of Academic Research in Business and Social Sciences, 11(15), 93-111.

Xiao, J. J. (2008). Applying behaviour theories to financial behaviour. (Ed.). Handbook of Consumer Finance Research (Pp. 69-81). New York: Springer.

Zaimah, R. (2011). Pengaruh pengetahuan, tingkahlaku dan pembuatan keputusan kewangan ke atas kesejahteraan kewangan pekerja sektor awam yang berkahwin (Unpublished doctoral dissertation), Universiti Putra Malaysia, Serdang. 